\title{
RENAISSANCE SELF-FASHIONING
}

From More to Shakespeare

Stephen Greenblatt

Cloth 272 pages $\$ 20.00$ November

\section{SHAKESPEARE AND THE PROBLEM OF MEANING}

Norman Rabkin

Forthcoming February

\section{THE LETTERS OF JOHN WILMOT, EARL OF ROCHESTER}

John Wilmot

Edited by Jeremy Treglown

Forthcoming January

\section{ESSAYS ON PERSUASION}

On Seventeenth-Century English Literature

Frank Livingstone Huntley

Forthcoming December

\section{THE SWORD OF THE SPIRIT}

Puritan Responses to the Bible

John R. Knott, Jr.

Cloth 208 pages $\$ 18.00$ Available

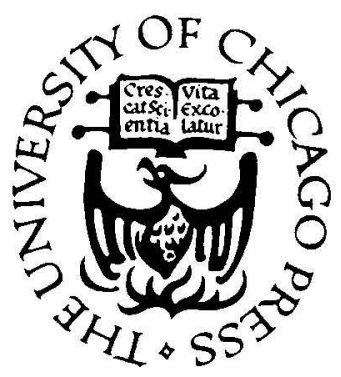

Visit Us at Booths $40 \& 41$

Chicago 60637 


\section{An internationally renowned}

scholar now probes the mysterious relationship between biology and culture...
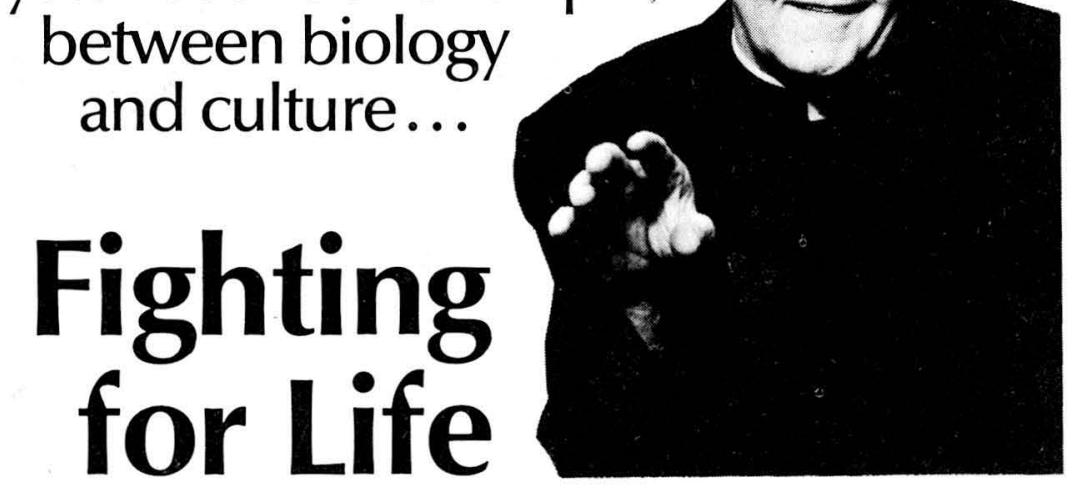

\section{Contest, Sexuality, and Consciousness BY WALTER J. ONG}

What accounts for the popularity of the macho image, the fanaticism of sports enthusiasts, and the perennial appeal of Don Quixote's ineffectual struggles? In Fighting for Life, Walter J. Ong addresses these and related questions, demonstrating the importance of contest in biological evolution and in the growth of consciousness out of the unconscious. (Coming in January) \$14.95

\section{Also by Walter J. Ong}

\section{Interfaces of the Word}

\section{Studies in the Evolution of Consciousness and Culture}

"A most convincing and truly indispensable book which must be required reading for anybody who plans to be or already is involved with language and literature." - Hans H. Rudnick, World Literature Today. "A triumph of humanistic scholarship." - Phillip K. Tompkins, Philosophy and Rhetoric.

\section{Rhetoric, Romance, and Technology}

Studies in the Interaction of Expression and Culture

"This scholarly, provocative and often witty book is a collection of essays on topics related to the rhetorical tradition in western culture.... A rewarding book." - America. "Ong is provocative." - Choice $\$ 19.95$
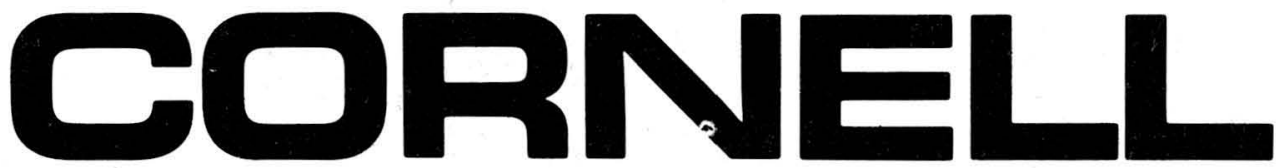